\begin{abstract}
This article analyses the impact of reterritorialization on classics of the stage. After reflecting on some particularities of classical works, the article focuses on The Misanthrope and Phaedra Britannica by British poet Tony Harrison, the first and rare successes of Molière, and particularly Racine on the Anglo-Saxon stage. It compares the main aesthetic features of Molière's and Racine's works with the modernizations operated by Harrison, and comments on the relevance of the historical and geographical transfer as a domestication strategy. While reterritorialization strategically includes the spectator, it does not so without a major impact on certain characteristics of seventeenthcentury French theatre. The fact that the plays have a strong aesthetic identity makes the transformations striking. Indeed, what makes up the identity of classical French theatre, namely the unity of action, characterization, passions, and, more generally, the nature of comedy and tragedy, is transformed by reterritorialization. Also dependent on reterritorialization, dramatic language, notably rhythm, semantics, and versification, is metamorphosed. These two case studies on the impact of historical and geographical transfer shed light on the points of disparity between the classical French theatre and the expectations of the modern English audience, and help to address other reterritorialized adaptations of classics.
\end{abstract}

Keywords: Harrison, Molière, Racine, adaptation, reterritorialization, aesthetics

\title{
Reterritorialization and Aesthetic Transformations: The case of Tony Harrison's Phaedra Britannica and The Misanthrope
}

\section{Introduction: Challenging classics through adaptation}

One effect of the institutional canonization of a work is that it reinforces the connection between all the elements that make up the substance of a work - notably subject, structure and style. The 'aesthetics' of classical works, a loose term referring to all the distinctive underlying principles of a work of art, is readily recognisable, defined and authoritative, and seems to be devoid of any contradictions or flaws. For example, one would not conceive Phèdre, Racine's most celebrated tragedy, written in a form other than that governed by seventeenth-century theatrical rules, and other than Racine's typical restrained expression and verse. Seventeenth-century French theatre indeed seems to be particularly strongly anchored in a defined and authoritative cultural identity. It constitutes a heritage perpetuated by the academic, artistic (notably the Comédie Française) and cultural institutions. Furthermore, the performance of these works heightens the resonance of the dramatic language and the various text effects, as well as it extends the range of classics beyond the classroom and maintains the canon alive in the wider public sphere. Viala's article 'Qu'est-ce qu'un classique?' in part explains why an impression of strong and cohesive aesthetic identity radiates from classical works. Viala argues that the canonization of a work results from a social pressure to respond to them as dictated by various academic and cultural institutions. In other words, a work becomes a classic because the institutions narrow our possibilities for describing it (see Venuti, 2008, pp. 28-29); it becomes an artificial construction that one accepts by convention. Some critics have argued that the process of canon formation derives from a social and political project (Martindale, 2008, p. 83-84) and from an operation of cultural production (Lianeri and Zajko, 2008, p. 7).

The act of deliberately proposing a new-fangled aesthetic through modification, subtraction or addition to the classical work in the adaptation process is flagrant, and thus potentially provocative and violent: the etymology of identity bears the sense of exclusion, 
identity being, according to the Oxford English Dictionary, 'the condition or fact that a person or thing is itself and not something else'. Several critics have used the concept of violence when referring to changes generated by the translation process, notably Auradha Dingwaney, Carol Maier, Colin Richards (see Sun, 2011, p. 159) and of course, Venuti, who has famously discussed 'the ethnocentric violence of domestication' in relation to translation in the Anglo-American world (Venuti, 1995, p. 61). Yifeng Sun (2011) distinguishes between 'gentle violence' in translation, which is 'of a benign nature, primarily to facilitate crosscultural communication in dealing with the otherwise linguistically or culturally untranslatable,' and 'abusive violence', when translation is 'manipulative,' 'destructive,' 'aggressive' or 'abrasive'. Another famous use of the notion, although it is more the term 'aggression' than 'violence' that is put forward, is found in the second stage of Steiner's fourstage hermeneutic motion (1998, pp. 312-319). After the first stage, which is the initiative to trust that there is something in the source text of value, comes 'aggression,' also controversially called 'penetration' - the invasive move of extracting and appropriating the meaning. In canonized texts, these two stages are reinforced. Because classical texts carry cultural weight, one usually considers them to be inherently very valuable. Interventions in translation are consequently more liable to be perceived as 'violent' or 'aggressive'. The sense of identity in the non-canonized work is less tangible: its aesthetic codes are less widely recognized, and can be apprehended and handled in various ways without the same sense of controversy.

Virulent reviews of free translations of canonical works are frequent to find, and this supports the idea that interventions on these works are readily regarded as an act of violence. Referring to Howard Hugo's and Robert Lowell's translations of Phèdre, in which the style is quite freely recast, critic Katherine Wheatley states: 'These two versions of Racine's masterpiece constitute the ultimate indignity to Racine, who has suffered many indignities at the hands of English imitators' (1967, p. xvi). According to a reviewer in The Times, Ranjit Bolt should be 'taken to the top of the tallest tower in the City and thrown off it,' for having disrespected Molière’s Les Femmes savantes (Bolt, 2010, p. 38). To mention a telling example, Bernard Knox has significantly entitled his review on Hughes's version of Aeschylus’ Oresteia (1999) and Euripides’ Alcestis (1999) ‘Uglification’. Knox decries intrusive words, some anachronisms and uses of different registers from those of the Greek play (see Hardwick 2008, p. 354). These reviews resonate with many critical discourses championing a traditional understanding of the canon: Harold Bloom in The Western Canon, for example, passionately argued the need to preserve the integrity of the canons and argued that one should refrain from altering it by making it easier to comprehend: 'Aesthetic value rises out of memory, and so (as Nietzsche saw) out of pain, the pain of surrendering easier pleasures in favour of much more difficult ones' (2014, p. 38).

When a change of setting entails a change in the aesthetic identity of a canonized work, in order to acknowledge fully the conspicuousness and significance of the transformation, one can argue that what is at play is more than a mere relocalization (denoting a simple geographical shift): 'reterritorialization' seems more suitable. ${ }^{1}$ The classical Latin etymon

\footnotetext{
1 The term 'reterritorialization,' coined by Deleuze and Guatarri in Anti-Oedipus (1972), was first used in psychoanalytic study on schizophrenia. These authors subsequently used the term, as well as the terms ‘territorialization' and 'deterritorialization,' in other contexts: in Kafka: Toward a Minor Literature (1986), the three terms are used in relation to the choice of language in postcolonial literary works, with a view to defining the concept of 'minor literature.' The terms quickly acquired popularity in social sciences, notably in anthropology and human geography. However, although Annie Brisset made a notable use of the terms in her study of a Québécois adaptation, equating the adaptation with 'an act of reclaiming, of recentring of the identity, a reterritorializing operation' (2000, p. 284), the three terms have not asserted themselves in the common terminology of the discipline of theatre translation.
} 
territorium denotes 'an area of land enclosed within the boundaries of a town', a territory is thus a space under the jurisdiction of a ruler, state, or group of people; a territory is what animals defend and fight for. As it necessarily follows a 'deterritorialization', 'reterritorialization' implies a violation of the space where certain rights were claimed, followed by the process of creating a new territory. It is a process that would apply to uprooting an aesthetic identity firmly entrenched in a given space through an adaptation.

Paradoxically, even though the change of setting can go beyond the relocalization of the classic, the setting of the original work is not necessarily what constitutes its 'territory' per se: seventeenth-century Paris in Molière's major comedies and the distant Athens and Rome in Racine's tragedies form an unclear background devoid of real structural importance. It is not so much the focal point of the action either: Phèdre's myth and the confrontation between Alceste and his society in Molière's Misanthrope have a resonance that transcends spatial boundaries. What is firmly historically-inscribed, what ties these plays to the cultural space where they originated, is the works' various aesthetic codes and traits. Style, in particular, plays a prominent role in rooting a classical work in a defined 'territory': ' 'le style, c'est tout,' and that's the trouble' maintains The Financial Times (30 July 1994) reviewing Ranjit Bolt's Cid at the National Theatre. In a letter to Louise Colet (16 January 1852), Flaubert argues that style is 'in itself an absolute way to see the world' (my translation). And in The Art of Literature, Schopenhauer argues that style is the gatekeeper of integrity in literature: 'To imitate another man's style is like wearing a mask, which, be it never so fine, is not long in arousing disgust and abhorrence, because it is lifeless; so that even the ugliest living face is better. [...] The language in which a man writes is the physiognomy of the nation to which he belongs' (2004, p. 11).

The paradox in classics is that they belong to a defined territory, but they also belong to no territory. This challenges two common assumptions. First, the core of the aesthetic identity of the canonized work is not as solid as it may seem. The fact that the various textual elements appear closely related in canonized literature is more an illusion stemming from our cultural appropriation of the work, rather than an inherent quality of the work. Second, as classical works are only partly non-territorial, they cannot be fully universal, even though they are repeatedly said to be so. Although some authors, notably Shakespeare, are believed to cross boundaries smoothly, several studies have refuted the cliché: one can quote a spirited article from The Guardian, 'Shakespeare, universal? No, it's cultural imperialism' (21 May 2012, Emer O’Toole). Racine and Molière have had some misfortune on the Englishspeaking stage: as The Sunday Times (18 October 1987) put it: 'If we are not careful, Molière could become one of the obstacles to a united Europe. How can you trade freely, let alone merge with a nation whose best comedy never travels?'. If anything is universal, it is often the substance, the gist of the action, the philosophical, anthropological and cultural resonances of the plot and character psychology. The style, however, often particularly idiosyncratic in classics, remains very territorialized.

Therefore, when a classical work is adapted to a defined modern setting, a double deterritorialization is at play: the territorialization of the non-territorial, and a deterritorialization of the historically-inscribed, as it will involve some stylistic and other formal changes. It is through this dual shift that the strong aesthetic identity of the classical work is altered.

If the substance of the source text stays in adaptation - although in a necessarily altered form because of the territorializing process - and the style is recast, the genre 'commits the heresy of showing that form (expression) can be separated from content (ideas) - something both mainstream aesthetic and semiotic theories have resisted or denied' as critic Kamilla Elliott has pointed out (quoted in Hutcheon and O’Flynn, 2013, p. 133). In line with Lianeri 
and Zajko's collective book, which posits that translation 'offers a key entry point of engagement with the question of what is a classic' (2008, p. 1), I contend that the separation between substance and style entailed by adaptation offers a valuable prism through which classics can be analysed.

Through the analysis of Tony Harrison’s Phaedra Britannica (1975) and The Misanthrope (1973), this article discusses the impact of reterritorialization on the aesthetic codes that make up the identity of Racine's Phèdre and Molière's Misanthrope. While the reterritorialization strategically includes the spectator, favours the understanding of the stakes of the source plays and is certainly responsible for the notable success of these adaptations, it significantly affects many characteristics of French seventeenth-century theatre. As the two case studies will show, the fact that the historical and geographical transfer calls for a 'deterritorialization' of Molière's and Racine's respective styles, generates the most significant aesthetic transformations.

Choosing Harrison's adaptations as case studies seems judicious: in addition to their great influence, unlike Malleson and Raine, and unlike Restoration adaptors who reworked the material very freely, Harrison does not restructure the original to the point of precluding a line-by-line comparison. Although one can read in the first lines of the introduction to Phaedra Britannica Harrison's project stands as the descendant of the Euripides-SenecaRacine filiation, the rewriting of Phaedra's myth is very different. Furthermore, the modernization of the play comes with regular heroic couplets, a form regarded by its defenders to be the most apt to convey the rhetorical strength of Molière's language (Wilbur, 1958, p. xi) or to imitate the noble and refined expression of Racine (Argent, 2010, p. xxi-lx). In other words, as Harrison's adaptations are simultaneously drawn towards the source and target axes, it is possible to measure the impact of the historical and geographical transfer.

\section{Phaedra Britannica: Transformation of Racine's Aesthetics}

As Harrison points out in his introduction of Phaedra Britannica, the whole play is condensed in the line 'La fille de Minos et de Pasiphaé' (2002, p. 116). Within Phèdre's veins flows an antagonistic blood - that of a civilising hero and judge of the underworld and that of a mother with barbarous sexuality. This twofold heritage shows through Phèdre's torment between her sacrilegious yearning for Hippolyte and the awareness of her fault, making her fight against herself with all the forces of her virtue. In the tragic dilemmas of Racinian characters, rightly or wrongly, one often tends to read 'interrogations on human liberty, on the relationship between humans and their passions and the world, on the transcendentalism of History' in accordance with a nineteenth-century- and part of twentieth-century-inherited metaphysical and moral construal of the plays, still popular nowadays (Forestier, 1999, p. xxi, my translation).

Thanks to the reterritorialization of the play into a Victorian colonized India, Harrison departs from sheer psychologism and transcendentalism: he transposes the myth into an anthropological and social reality. The moral antagonism embodied by Minos and Pasiphaé is integrated in a duality that only started to flourish in the Enlightenment, thus after Racine: 
that of civilization and non-civilization. ${ }^{2}$ In Racine, Phèdre is at the centre of the play; the incest and adultery constitute the heart of the plot and suffice to nourish the tragedy - in his introduction, Harrison recalls that much of the audience would go and see the play only to relish the eponymous character's few famous tirades played by Sarah Bernhardt. However, in Harrison, the monopoly of tragedy is no longer held by the sacrilegious love of Phèdre: Phaedra Britannica concretizes the timeless dimension of the myth into a historically circumscribed framework. The individual incarnation of the conflict between order and hybris is magnified to the level of the civilization shock between two cultures and antagonistic worldviews.

As Harrison recalls in his introduction, according to Victorian psychology, India epitomises a transgressive and chaotic otherness, a land wherein the forbidden, the taboo and the repressed are given free rein. Against this dark-gods-haunted land stands the Governor of the Raj [Thésée]: a heroic British imperialist and, according to Victorian imaginary, protector of the civilized world (Ward, 1970). Hippolyte, in Racine, son of Thésée and of the Queen of the Amazons, becomes the son of the Governor and of a 'barbarian, half-wild' Rajput princess (2002, p. 175). Therefore, he becomes a 'half-breed' Eurasian (p. 178). The independent, chaste and wary nature of Racine's Hippolyte, being devoted to the solitary practice of 'the art of Neptune' in the forests and on the banks, takes up a whole other meaning in the character of Thomas Theophilius, who stands half-way between civilization and wildness.

The irruption of violence within alliances - in Phèdre, the father backfiring on the son -, a metonymic event of a shattering moral order, is a prerequisite of Racine's drama, taken from Aristotle's Poetics. In Harrison, not only does the family disunion mark the destruction of what is left of harmony, but symbolises the clash of civilizations. The disgrace of the fault is attributed to the racial status of Thomas Theophilius, giving an opportunity for the Governor to profess vehemently the truisms of colonial ideology against Oriental alterity:

\section{THESEE}

Et ne devrait-on pas à des signes certains

Reconnaître le cœur des perfides humains?

(IV-ii, l. 1039-1040)
GOVERNOR

A beast in human shape! I'd like to brand ANIMAL on his flank with my own hand! (2002, p. 185)

Later the Governor reuses the term 'animal,' suggesting that Thomas Theophilius irrevocably belongs to the savage world: 'When did this animal first start to prowl?' (p. 185).

In Racine's plays, one usually sees characters' fates already sealed from the start. Jacques Scherer, by proposing a backward dramaturgical reading of the plays, rehabilitates the liberty of Racinian characters (1960, p. 265-269): albeit shackled to their passions, Racine's characters nonetheless remain the true owners of their decisions. However, the vicelike grip in which Racine's characters struggle tightens in Harrison's adaptation; the imperialist framework confers a more concrete and more rigid aspect to fatality. Although Racine explicitly recalls that Aricie, Hippolyte’s lover, comes from Thésée’s rival family, in Phaedra Britannica, the political prohibition of love is intensified by an inflexible ideological obstacle. The political tensions of a forgotten Athena give way to a racial conflict more directly visible to the spectator. Indeed, while political rivalry may be anecdotal, the ethnicity, in Harrison's world, cannot pertain to the temporal sphere.

Thus, it can be argued that by placing a timeless myth into a circumscribed spatial and temporal framework, Harrison has managed to retain, if not to reinforce the effects that Racine's drama should convey: terror and pity do emerge with strength in the audience of

\footnotetext{
${ }^{2}$ As Gabriele Rippl remarks, the expression ‘civilization and its discontents' used by Harrison in his introduction (2002, p. 118) is the English title of an article by Freud entitled 'Das Unbehagen in der Kultur' (2004).
} 
Phaedra Britannica. Moreover, the fact that the psychological drama is backed by a social structure that the audience recognises and, for some, in which the audience recognizes themselves, facilitates the identification process. Harrison's adaptation indeed has an underlying contemporary political resonance: as Rippl notes, Leeds, Harrison's birth city and the neighboring town Bradford both have a significant Indian, Pakistani and Bangladeshi diaspora, and are subject to racial tensions (2004, p. 177). Although this political resonance favours the efficiency of the play, some reviews have noted flaws in the modernization process. For example, the article entitled 'Phaedra Spiced with Curry' published in the New York Times (12 October 1975) deemed the first marriage between the Governor and the Indian girl, the fact that he invokes the Indian god Shiva, and, that his wishes are fulfilled, barely credible.

Another subversion of the aesthetic model inherited from Aristotle comes into play: the tragic hero must be 'the sort of man who on the one hand is not of outstanding virtue and justice, and who comes upon disaster not through wickedness or depravity, but because of some mistake' (Aristotle; in Baxter and Atherton, 1997, p. 95). Although in Phèdre, the death of the son is indirectly caused by the calumny professed by a third person, therefore, resulting from the father's error, the Governor's attitude is nevertheless in every respect reprehensible for a twenty-first century audience. This confirms an offending morality that was already foreshadowing: taking pride in his carnal pleasures with young natives, the Governor makes himself a loathsome representative of the chauvinistic hegemonic ideology perpetrated against the indigenous people. In Harrison, the model of the antique hero is disfigured; for the modern audience, the Governor is incontrovertibly iniquitous and his dignity is forevermore stained. He makes himself more detestable than Racine's Theseus, whose frivolous actions are gracefully downplayed by his son's apologetic lines at the opening of the play.

The subversion of the tragic hero entails the weakening of Racine's 'sublime'. In Racine, a majestic beauty rises from the horrid - a beauty in the character nobility within catastrophe, in the repented error and in the absconding of any forthright abjection. Where can one find the compensating source of pleasure and sublime, when the 'beauty of characters' is tarnished by a disgraceful ideology? The answer partly lies in the spatial framework chosen for the play: India. While in Racine the spatial framework is indistinct and without real structural importance, in Phaedra Britannica, the Indian land is extremely palpable, visible, audible and odorous. Teeming with monsters, tigers and other creatures, haunted by dark gods, this jungle repels and mesmerizes at the same time. The setting is frequently given vivid descriptions:

Déjà de sa présence avec honte chassée Dans la profonde mer Oenone s’est lancée. On ne sait point d'où part ce dessein furieux. Et les flots pour jamais l'ont ravie à nos yeux. (V-vii, l. 1665-1668)
No blacks and none of us (but you)'d give chase Into that swampy beast-infested place. The jungle swallowed her. No search would find Much more than shreds of sari left behind. (2002, p. 200)

The sea into which Oenone dives, a disquieting immensity in the Greek imagination, now becomes an utterly aggressive jungle. The allusion to a land that oversteps the civilizational scissions 'No blacks and none of us,' the adjectival proliferation 'swampy beast-infested,' and the uncanny personification 'The jungle swallowed her' emphasise the ferociousness of this other immensity. From the reflexive verb 'se lancer,' hinting to Oenone's voluntarism, Harrison chooses a full active turn of phrase, 'swallowed her,' making the jungle an active body and making the character a victim.

More than a mere realm of chaos, more than the hereafter of the known and civilization (and of non-civilization, in fact), India in Phaedra Britannica is a personified, mystical and 
omnipotent space; half-revered, half-feared, a sort of a godlike entity. When Racine’s Thésée summons Neptune, India is the sovereign power invoked in an apostrophe by the Governor in the death sentence spoken against his son:

If you cherish me in your dark heart,

India, tear this animal apart! (2002, p. 186)

In fact, this sentence marks yet another distancing element with Racinian aesthetics. In Phèdre, gods are mere allegories, rhetorical figures that are constantly invoked but who refrain from intervening, apart from Hippolyte's death at the end of the play. Their function is mostly ornamental: 'In Phèdre, gods have no other reality - yet a terrifying reality coming from repressed drives - than that of the character's consciousness that creates them verbally' (Forestier 1999, p. 1638, my translation). In Harrison, not only does India harbour countless dark gods, but India, itself, is deified. The malefic and vengeful divinity is therefore omnipresent: on the soil upon which the characters tread, in the air they breathe and in the scorching sky that smothers them. It is the entire nature that is cursed and haunted. Venus, goddess of love, becomes Shiva, Hindu god of absolute knowledge, of creation and destruction. Shiva, thus, is a vivid representative of the Racinian tragic: both an Apollo and a Dionysus, both a Minos and a Pasiphae. Like India, Shiva is another omnipotent deity.

Yet, as Alan Riddell remarks in The Sunday Telegraph, the real evil is the climate: 'although he [Harrison] mentions a hierarchy of alien deities, the villain of the piece is the climate' (14 September 1975). Just as one is in wait for the tragic catastrophe, one expects the explosion of the burning skies. The stage directions indicate from time to time 'thunder'. The sun holds a more prominent place in the Pantheon: Racine's heroin, daughter of Pasiphae, bears sexuality within her; Harrison's heroin bears the climate responsible for her profane desires:

Noble et brillant auteur d'une triste famille, Toi, dont ma mère osait se vanter d'être fille, Qui peut-être rougis du trouble où tu me vois, Soleil, je te viens voir pour la dernière fois. (I-iii, l. 169-172)
That's where it all started, that red fire.... ... blinding, consuming... Ayah its light sinks in, right in, to scrutinize the sordidness concealed behind my eyes. This is the last time that I'll have to gaze on those all-seeing, penetrating rays. (2002, p. 149)

Characters fight against their inner passions just as much as they do against the external world. Being a real scourge that overwhelms the earth, nature and humans, the suffocating heat reigns ruthlessly, until Phèdre's death, at which point, extraordinarily, the ardent sun absconds and the harvest comes:

Déjà je ne vois plus qu'à travers un nuage Et le ciel, et l'époux que ma présence outrage; Et la mort à mes yeux dérobant la clarté Rend au jour, qu'ils souillaient, toute sa pureté. (V-vii, l. 1641-1644)
I hear it starting now, the rain, cool rain giving the blood-red earth new life again. Rain. Rain. Like purdah curtains. When I die the dawn will bring you all a clearer sky. (2002, p. 206)

At the same time, a direct consequence of the reterritorialization and a contributor to it, an essential part of the aesthetic reworking of Racine's play is attributable to stylistic changes. Often, one admires (or criticizes) Racine's language for the simplicity of his vocabulary and yet its ability to create powerful effects. The discrepancy that appears in Racine's stylistics - the austere restraint of the lexis against the strength of passions - is, in a way, archetypal of the tension that emanates from the verse form. Racine's alexandrine 
guarantees order, a rational discourse, a controlled expression. It embodies the resisting reason against unruly passions; it is Minos standing in the way of Pasiphae.

In their introductions and prefaces, translators usually devote several paragraphs to the aesthetic particularities of Racine's verse and to the necessity to strive reproduce some of its aspects (see Argent, 2010; Bartlett, 1996, p. 68; Wilbur, 1958, p. xi). Rarer are those who, like Robert Lowell and Ted Hughes, give themselves over to radical stylistic freedom in their translations. Lowell colours his heroic couplets with a great many images, to the point of almost veering his Phèdre towards a British Restoration play: as he himself admits, an 'unracinian humour and bombast' permeates the translation (1961, p. 8). Hughes uses very short lines with concrete images. Moving away from a fairly abstract expression of passions and inner turmoil, Hughes uses lexical fields close to his own poetic practice and suffuses his text with intensely sensorial language expressing the power of nature.

In these two cases, unlike in Harrison's adaptation, the new style stems from the authors' own poetic practices and are not corollary of any change of setting. The setting chosen by Harrison, as powerful as it is exotic, calls for an abundant and colourful lexis, which was criticized by critic David Gervais: 'When Harrison seeks to make it sound overtly poetic the result feels clotted and overwritten' (2009, p. 309). On the other hand, it can be maintained that the overwritten style actively contributes to creating an oppressive atmosphere, which expresses the characters' overwhelmed state.

The crushing effect of Harrison's language is also vividly conveyed by the verse form used: in the introduction to his play, Harrison describes the iambic rhythm as 'heartbeats and blood throbs in the ear of British India' (2002, p. 139). Being alien to modern British theatrical tradition, rhyme is an utterly exotic form, even transgressive. In the heroic couplets of Phaedra Britannica, one is tempted to hear only the continuous and deafening triumphal sound of irrationality.

The transgressive imposes itself on every scale: in the text, one notes a rhythmic anarchy superimposed onto the prosodic regularity, something that can also be found in Racine, but more sporadically and less emphatically. The difference in rhythmic deployment in this excerpt is a case in point:

PHEDRE

J’ai suivi tes conseils, je meurs déshonorée. ENONE

Vous mourez?

PHEDRE

Juste ciel! Qu'ai-je fait

aujourd'hui?

[...]

Mourons. De tant d'horreurs qu'un trépas me délivre.

Est-ce un malheur si grand que de cesser de vivre?

(III-iii, l. 838-841)
MEMSAHIB

All I deserve’s dishonour. Death. Disgrace. AYAH

Death! Death!

MEMSAHIB

What have I done? What have I done?

$[\ldots]$

Death's the only answer. Death. A swift release from pain. For me and for my conscience, peace. (2002, p. 177)

Unlike Racine's alexandrine, Harrison's verse is not treated as a unified structure; ${ }^{3}$ the syntagmatic and paradigmatic axes are perpetually in conflict. Compulsive repetitions, disordered punctuation hindering enunciation and syntactic disruptions confirm that verse is more under the influence of Pasiphae than under the auspices of Minos. The prosodic tension

\footnotetext{
${ }^{3}$ In passages when tension is paroxystic, Racine's text also contains lines in which regularity is disturbed 'Voilà mon cœur. C’est là que ta main doit frapper.' (l. 704). Monosyllabic orders are vivid examples: 'Frappe.' (1. 707), 'Donne.' (l. 711)
} 
is particularly flagrant in Memsahib’s first speech: the first line is a trimeter, the second and the last lines are tetrameters. The prosodic framework collapses, being unable to contain the strength of the inner turmoil:

\section{PHEDRE}

N'allons point plus avant. Demeurons, chère Oenone. Je ne me soutiens plus; ma force m'abandonne.

Mes yeux sont éblouis du jour que je revois, Et mes genoux tremblants se dérobent sous moi. (I-iii, l. 153-156)
MEMSAHIB

... no more ... I can't. Must stop. No strength! ... Can't move another step. Dazzled. My eyes. O ayah, I can't bear the sudden brightness. Sun. Glare. (2002, p. 148-149)

In giving a definition of tragedy in the preface to Bérénice, Racine offers material for a conclusion: 'A simple action, sustained by the violence of passions, the beauty of feelings, and the elegant expression' (my translation). While with Phèdre, Racine clearly moves from a 'plot tragedy' to a 'character tragedy' - 'Progress of action was no more the result of confrontations between the characters (as in Bérénice), but in conflicts that took place within the conscience of a single character' (Forestier, 1999, p. 1615, my translation) - in a way, Phaedra Britannica runs counter to the evolution of Racine's works: the new setting places emphasis upon secondary aspects of the plot. While the political conflict forms a distant and faint backdrop in Racine's play, it becomes very prominent in Phaedra Britannica. While the action remains the same, it unfolds on the background of a social structure that makes the reading more complex. The violence of passions is reinforced - or diminished according to sensibility: reinforced by the brutality of Harrison's verse; or diminished for this very reason, alleviating the contrast between the expression and the expressed, or, according to Gervais, because of the semantic overabundance. The beauty of feelings is sometimes tarnished by the occasional invectives and interpellations that recall colonial ideology. The elegant expression is on the one hand preserved by a rigid versification, yet on the other hand violated by this same rigid versification disrupted by panting rhythm.

\section{The Misanthrope: Revitalization of Molière’s Aesthetics}

Compared to Racine, Molière's plays have a certain flexibility that lends itself quite well to adaptation. The numerous free adaptations of Molière's plays testify to this, and to all intents and purposes, Molière himself rearranged existing material when writing his plays. His comedies stage characters using various styles and registers and language appears to be spontaneous, even in his verse plays. The comic genre also calls for an adaptation that strives to keep the humour relevant to the target culture. The reterritorialization has fewer implications than in Phaedra Britannica, even though, as we shall see, it does undermine the potential of a uniform understanding of the play.

Harrison chose to transfer his play into 1966 France rather than 1973 as celebration of the tercentenary of the creation of Le Misanthrope. At first glance trivial, this difference is yet far from being insignificant: as Harrison points out in the introduction to his adaptation, the play stems from an article from the Canard Enchaîné by André Ribaud entitled 'La Cour,' which draws a parallel between De Gaulle’s political régime and Louis XIV's monarchy. If the action was strictly contemporary to the creation of the adaptation, i.e. under Pompidou, the monarchical references would not have the same structural role. As much as enabling to retain the allusions to the court and to the king in the original, this adjustment makes these allusions topical. 
Although Charles de Gaulle is never explicitly mentioned, these allusions are yet stressed by various typographical marks:

if there's anything at all I can do,

Elyséewise, a place, an interview,

Just say the word. Most people are aware

just what my standing is with those 'up there'.

There can't be many men much more au fait

With all that happens at the Elysée.

I'm 'in' with those that matter, even HE

treats me like his own; yes, honestly! (2002, p. 40)

Capital letters, inverted commas, italics and, sometimes, compound words or neologisms, are used almost systematically when characters evoke power. Their use suggests a particular standpoint on authority: while being perfectly normal in the original, the 'court' is here coloured with an eccentric overtone. In other words, the paradoxical idea of a monarchic presidency translates into an unconventional textual materiality, which calls for an affected vocal deployment in performance. Thanks to these artifices, a certain 'peopolization' emerges around the character De Gaulle, and by metonymy, around Célimène's 'court'. 4 However, the irony cast on De Gaulle's 'court' only backs up the initial project of Le Misanthrope, which is the comic confrontation between an opportunistic and courtly society, and exacerbated frankness embodied by Alceste. The transfer from Louis XIV to Charles de Gaulle makes some of the seventeenth-century values shift naturally towards modern societal phenomena: mundanity becomes swanky society, affection becomes snobbism, the honnête homme is the politically correct or the right-thinking, civility becomes opportunism. This transfer makes it possible to reproduce the conniving comic that had emerged for the first time in Le Misanthrope between the characters-'society people' and the audience-'society people', who find themselves at the same time confronted to an eccentric. Making it easier for the modern audience to identity with the characters, the historical transfer recreates ' $l e$ rire dans l'âme', to quote Donneau de Visé.

There is more than sheer domestication. In his introduction Harrison does not advocate any politicization of his characters, and indeed, no partisan or ideological allusions are slipped into the text. However, thanks to the somewhat ironic posture against De Gaulle's regime, it is quite tempting to see Alceste as a political militant, an anarchist, a Marxist, a reactionary, a pre-soixante-huitard, or an antipolitical character. Indeed, the change in setting prompts the audience to delve into the potential direct resonances into their contemporary society and to draw a socio-political reading from it. ${ }^{5}$ This type of reading would be in line with the political theatre genre that was emerging in 1970s Britain and flourished in the subsequent years. Furthermore, one cannot exclude any potential subliminal association between de Gaulle's monarchy and British monarchy, although journalistic reviewers have not mentioned it. The fact that the action does not take place in contemporary England enables, on the other hand, to tone down the domestication process and to hinder an all-tooconscious identification in the British audience.

Although the reterritorialization is not as intrusive as Phaedra Britannica, it does entail an axiological duality that problematizes the reading of the play. Although Harrison aspires to

\footnotetext{
${ }^{4}$ This peopolization will be developed in the adaptations by Neil Bartlett (1988) and Martin Crimp (1998), where the 'media chic' gives a more tangible setting to the affected society of which Célimène is the embodiment and Philinte the defender.

${ }^{5}$ A political reading of Harrison's adaptation of Euripides's Hecuba (2005) is equally tempting as Harrison's introduction to the play makes anachronistic correspondences between Euripides's play and the conduct of the invasion of Iraq in 2003.
} 
consolidate rather than weaken the stakes of the original play, and although the references to the presidential 'court' are, in fact, only sporadic, this new 'eccentricity' almost stands in competition with the main one, namely the paradoxical love between an atrabilious character and a coquettish young lady, to the risk of obscuring it. Indeed, although the revival at the National Theatre in 1989 has mostly been positively welcomed by reviewers, The Times pointed out that Harrison's version did not lend itself easily to the contemporary: 'the structural purpose has vanished [...]. The play has slipped back into the comic never-never land' (22 March 1989), de Gaulle’s France being quite different to that of Mitterrand. ${ }^{6}$

As in Phaedra Britannica, the most striking gap between Molière’s aesthetics and Harrison's adaptation can be found on the stylistic level. Anchoring a play into a new time frame cannot function without linguistic domestication. 'La langue de Molière', a timehonoured expression, is metamorphosed by the reterritorialization in Harrison's The Misanthrope.

Alceste's frequent swearwords and blasphemes apart, Le Misanthrope is often erroneously said to be a play in which a certain stylistic unity transcends the different temperaments. Characters in Le Misanthrope do not use language in a uniform way. According to their linguistic identities, Peacock groups them into four categories:

(1) Verbal Nakedness: Alceste and Du Bois, characters who are reluctant or unable to dress up linguistically; (2) The Overdressed: Arsinoé, Oronte, Acaste and Clitandre, characters whose elegant language does not correspond to any inner reality; (3) One Dress too Many: Célimène, a character with an extensive linguistic wardrobe, in fact too extensive for her own good; (4) The Best Dressed Couple in Town: Philinte and Eliante, language for all occasions. (1987, p. 75)

Characterization mainly stems from uses of semantic fields that reflect the character's psychology. Although Célimène uses a wider range of tones and registers, the other characters' linguistic identities are very confined. Nevertheless, in Harrison's adaptation, registers vary on a horizontal axis and not according to temperaments. To accompany the historical transfer cohesively and to reflect society people most efficiently, the coquettish Célimène, the marquises as well as reasoning Philinte use a highly idiomatic, familiar, loquacious and light language. If an informal register is to be expected from Alceste: 'Call him a bastard and everyone hoorays' (2002, p. 33), one can be surprised to hear from Philinte 'bitchy wits' (37) or Eliante who says 'his monstrous mistress with enormous bubs' (62), as Peacock points out (2004, p. 215). As the stylistic contrasts between the different characters are reduced, the emphasis on Alceste's tribulations may lose its efficacy.

Stylistic identity does exist, though, but essentially through the rhythmical development of the verse. In the adaptation, the contrasts between Alceste's virulent language, Célimène's versatile rhetoric and Arsinoé's restrained expression stem from the more or less pronounced fragmentation of the verse with punctuation. Seemingly a rigid and constraining system, Harrison's rhymed iambic pentameter proves to be very eclectic. As a way to limit the potential collision between the dramatic language and the new setting, Harrison had to place emphasis on the naturalness of language. Freed from the constraint of the hemistich, Harrison's verse liberally indulges in enjambment, which becomes an efficient instrument of characterization:

[...] the rather rocking rhythm of Philinte, both conciliatory and somewhat complacent; the barbed wit of Célimène, where the end-stopped couplet of Pope was effective; the

\footnotetext{
${ }^{6}$ In the same way, Scottish productions of this same play in 1978 at the Perth Theatre, or at the Athenaeum, Glasgow, have been successful, but have triggered similar criticisms (see Peacock, 1993, pp. 144-145).
} 
sly insinuating rhythm of Arsinoé; the staccato oiliness of Oronte; and leaving a much wider scale of variations for Alceste: implacability, satirical outrage, baffled love. (2002, p. 9)

Without playing down the strength of rhythmic contrasts, homogenising language registers enables all characters to engage in verbal comedy. While in the original play, only Alceste uses language eccentrically, all of Harrison's characters prove extravagant in their use of language. This is another domesticating strategy: the audience can laugh at, and with, every character. While Molière does not clearly choose sides between Alceste and Philinte, paving the way for a critical debate which will last several centuries, it has often been said that Alceste's hyperbolic, sometimes pseudo-tragic language does tend to discredit his diatribes. By not only entrusting Alceste with linguistic eccentricity, Harrison further avoids the potential of a uniform reading.

In his introduction, Harrison explains that, in the first version he wrote, when the decision to transfer the action into the twentieth century had not yet been made, he updated linguistic structures rather than the lexis to modernize his text. In the first version, the style could have been similar to that of Richard Wilbur's translation. The published version stems from a resemanticization of a text in which the strength of language comes more from a strong rhetoric than from an abundant lexis. Molière's verse is flexible, but subordinated to a rigorous rhetoric; it is resourceful, but always subject to a certain semantic restraint. As Harrison puts it: 'The salient feature of Molière's verse is its vigour and energy, rather than any metaphorical density or exuberant invention' (2002, p. 5). The following extract illustrates how Harrison departs from this:

Et je ne hais rien tant, que les contorsions

De tous ces grands faiseurs de protestations,

Ces affables donneurs d'embrassades frivoles,

Ces obligeants diseurs d'inutiles paroles, Qui de civilités, avec tous, font combat, Et traitent du même air, l'honnête homme, et le fat. Quel avantage a-t-on qu'un homme vous caresse, Vous jure amitié, foi, zèle, estime, tendresse, Et vous fasse de vous, un éloge éclatant, Lorsque au premier faquin, il court en faire autant? Non, non, il n'est point d'âme un peu bien située, Qui veuille d'une estime, ainsi, prostituée; (I-i, l. 43-54)

There's nothing I loathe more than empty grins And cringing grimaced and wagging chins, Politeness-mongers, charmers with two faces, Dabblers in nonsensical fine phrases, Outvying one another in their little game Of praise-me-I'll-praise-you. It's all the same if you're idiot or hero. What's the good of friendship and respect if it's bestowed on any nincompoop and simpleton your praiser-to-the-skies next happens on? No! No! Not one right-thinking man, not one 'd want such ten-a-penny honours done. (2002, p. 29) 
Tuning in to the British audience's taste for verbal comedy, Harrison almost transformed a comédie de mours into a kind of boulevard comedy. The choice of a copious and inventive style instead of a more limited lexical corpus will be pursued in adaptations following Harrison's. The advent of a light language has turned out to be the most efficient ingredient for revitalising a type of comedy that, for a long time disappointed expectations on the English stage (see Ploix, 2016).

\section{Conclusion and further reflections}

These two case studies have shown that in the case of canonical plays especially, the effects of historical transfer do not limit themselves to pure domestication. Because a translation (and a fortiori an adaptation) is always a specific exegesis of the original material, the specific territorialization of what might be regarded as a timeless and universal substance generates an underlying socio-politicization that might problematize our understanding of the play.

Reterritorialization modifies the hierarchy of the elements of the plot, it redefines the link between the different characters, the dramaturgy and the nature of the play, and it generates two competing axes of reading. Most crucially, reterritorialization cannot take place without a profound stylistic recast. The analysis carried out in this article also showed that by subverting them, adaptations can highlight many aesthetic components of canonical plays.

One may deem the change of the original aesthetic identity generated by the adaptations illegitimate because of the canonical status of the two plays. However, the fact that, as I argued in the introduction, classics are only partly non-territorial and partly universal makes adaptations inevitable. As Frank Kermode points out in his famous essay The Classic: Literary Images of Permanence and Change, classics 'must always signify more than is needed by any one interpreter or any one generation of interpreters' (quoted in Lianeri and Zajko, 2008, 5). In other words, classics have a 'surplus of signifier,' an excess of meaning which calls for continual reinterpretation through translations. Central to Lianeri and Zajko's introduction to Translation and the Classic: Identity as Change in the History of Culture is the paradoxical idea that, although a classical work is a culturally-bound fixed object, it needs to be reinvented; an idea also present in Kermode's essay: '[t]he necessity of translation indicates that no aspect of the classic can survive in the present in an unmediated form; while, at the same time, the very existence of translations affirms that it is impossible simply to repudiate the idea of cultural survival' (2008, p. 10). The translations of classics, in turn, act as one cultural practice through which the original texts acquire their canonized status. Hardwick discusses how translations assert the notion of the classic, by ascribing value to the original works (2008, p. 341). Geertsema goes as far as to challenge the idea that classics 'precede' the translation: 'there is a very real sense in which the classic is brought into being by translation, since the translation is what makes it accessible for reading in the language into which it is translated' (2008, p. 111).

It can therefore be argued that for all the subversions they inflict to the aesthetic identity of the original plays, Harrison's adaptations have contributed to the canonization of Racine and Molière. Harrison's adaptations are indeed interesting to study because they disprove a common place that seemed widely acknowledged, namely the inaccessibility of Molière's and Racine's theatre on the English-speaking stage. Phaedra Britannica is the first production of a Racinian play at the Royal National Theatre, London and Harrison's 
Misanthrope is the first major Molière success at this theatre house. ${ }^{7}$ Of the 96 plays that made the first chapter of the history of the National Theatre - from its creation in 1964 to when it migrated from the Old Vic to South Bank in 1976 - Harrison's The Misanthrope is the twelfth most performed play, with a total of 82 performances. Only highly celebrated playwrights, such as Shakespeare, Stoppard, Shaffer and Congreve had been able to outrun this number. After this triumph, Harrison became the National's resident poet and adapted many other plays for performance, notably a medieval mystery in 1985, The Oresteia (1981) and Hecuba (2005). Harrison's Misanthrope subsequently travelled to Washington, Broadway and Scotland, revived in 1989 at the National Theatre in coproduction with Bristol Old Vic and again by Bristol Old Vic in 2010, in an updated version by Harrison. Most reviewers, often hostile towards classical French tragedy, praised Phaedra Britannica, as the adaptation revitalized English spectators' understanding of the issues raised by the play and in particular the dichotomy between rigid moral codes and transgression. In view of the positive fortune that seventeenth-century French classics enjoyed on the Anglophone stage thanks to Harrison's adaptations, one should refute the idea of 'violence' that one tends to associate with the change in aesthetic identity in classics: 'Translation can be supplicatory and interrogative rather than necessarily predatory’ as Hardwick maintains (2008, p. 362).

Furthermore, although Harrison was not the first playwright to adapt Molière and Racine, he was the one who influenced future generations of translators. Harrison seems to have revived the adaptation as a genre, which was slow to settle. In England and in America, ${ }^{8}$ apart from Craig Raine and Miles Malleson, before Harrison, translators of Molière and Racine, notably Kenneth Muir, Margaret Rawlings, Georges Dillon, Wallace Fowlie, Howard Hugo, Samuel Solomon for Racine's drama, and Richard Wilbur, Donald Frame, Morris Bishop, John Wood for Molière, generally refrained from domesticating the originals. Much later, Ranjit Bolt will recognise that adaptation as a genre and $a$ fortiori the success of Molière on the English-speaking stage owes much to Harrison: 'Since that wonderful Old Vic production (which first made me want to translate French verse comedies), adaptation has become a theatrical tic in this country' (The Guardian, 9 February 2008). As Harrison created a new paradigm of theatre translation, one can follow critic Martindale when he points out that not only can translations of classics create the status of classics for the original works, but translations can become themselves classics (2008, p. 85).

\section{Bibliography}

Argent, G. A. (2010). The Complete Plays of Jean Racine. Vol. 1, The Fratricides. University Park, Pa.: Pennsylvania State University Press.

Bartlett, N. (1996). Neil Bartlett: A Different Night out in the Theatre, in Conversation with David Johnston. In D. Johnston (Ed.), Stages of Translation (pp. 67-74). Bath: Absolute Classics.

\footnotetext{
${ }^{7}$ Tartuffe by Richard Wilbur (1967), which was more a translation than an adaptation, had faced mixed reviews at the National.

${ }^{8}$ It is less the case in Scotland: in search for a national identity in the second half of the twentieth century, Scottish theatre significantly built itself around adaptations of French classics (see Peacock, 1993). Before being performed in London, Almeida Theatre, Craig Raine’s adaptation was premiered at Glasgow Citizens Theatre.
} 
Baxter J. \& Atherton P. (Eds.). (1997). Aristotle: Poetics, (G. Whalley, trans.). Montreal et al.: McGill-Queen's University Press.

Bloom, H. (2014). The Western Canon. Boston, MA: Houghton Mifflin Harcourt.

Brissett, A. (2000). The Search for a Native Language: Translation and Cultural Identity. (A. Gill \& . Gannon, trans.). In L.Venuti (Ed.), The Translation Studies Reader (pp. 281311). London: Routledge.

Forestier, G. (Ed.). (1999). Racine: Euvres complètes. Bibliothèque de la Pléiade. Paris: Gallimard.

Forestier, G. (Ed.). (2010). Molière: Euvres complètes. Bibliothèque de la Pléiade, Vol. 2. Paris: Gallimard.

Geertsema, J. (2008). Between Homage and Critique: Coetzee, Translation, and the Classic. In A. Lianeri \& V. Zajko (Eds.), Translation and the Classic: Identity as Change in the History of Culture (pp. 110-128). Oxford: Oxford University Press.

Gervais, D. (2009). Beyond Tragedy: Ted Hughes, Racine and Euripides. In Roger Rees (Ed.), Ted Hughes and the Classics (pp. 300-323). Oxford: Oxford University Press.

Hardwick, L. (2008). Translated Classics Around the Millennium: Vibrant Hybrids or Shattered Icons? In A. Lianeri \&V. Zajko (Eds.), Translation and the Classic: Identity as Change in the History of Culture (pp. 341-366). Oxford: Oxford University Press.

Harrison, T. (2002). Plays 2: The Misanthrope, Phaedra Britannica, The Prince's Play. London: Faber \& Faber.

Hutcheon, L. \& O’Flynn, S. (2012). Theory of Adaptation. (2nd ed.). London: Routledge.

Johnston, D. (2004). Securing the Performability of the Play in Translation. In S. CoelschFoisner \& H. Klein (Eds.), Drama Translation and Theatre Practice (pp. 25-39). Peter Lang: Frankfurt.

Lianeri, A. \& Zajko V. (2008). Translation and the Classic: Identity as Change in the History of Culture, Oxford: Oxford University Press.

Martindale, C. (2008). Dryden's Ovid: Aesthetic Translation and the Idea of the Classic. In A. Lianeri \& V. Zajko (Eds.), Translation and the Classic: Identity as Change in the History of Culture (pp. 83-109). Oxford: Oxford University Press.

Peacock, N. (1987). Verbal Costume in Le Misanthrope. Seventeenth-Century French Studies, 9(1), 74-93.

Peacock, N. (1993). Molière in Scotland. Glasgow: University of Glasgow French and German Publications.

Peacock, N. (1994). Translating Molière for the English Stage. Nottingham French Studies, 32, 83-91.

Peacock, N. (2000). Molière. In O. Classe (Ed.), Encyclopedia of Literary Translation into English (Vol. 2, pp. 956-961). London \& Chicago, IL: Fitzroy Deaborn Publishers

Ploix, C. (2016). 'Sorry for the rhyme, not the sentiment:' Traduire Molière et Racine pour la scène anglaise: le problème de l'alexandrin et l'exemple des trois 'McGoughières'. [Translating Molière and Racine for the English stage: The problem of the alexandrine and the example of the three 'McGoughières']. In I. Guénin \& B. Poncharal (Eds.), Les sens en éveil: traduire pour la scène, Palimpsestes 29 (pp. 103-125). Paris: Presses Sorbonne Nouvelle. 
Rippl, G. (2004). Culture and Transgression: Phaedra's Illicit Love and its Cultural Transformations. In J. Schlaeger (Ed.), Yearbook of Research in English and American Literature, 20 (pp. 165-182). Tübingen: Gunter Narr Verlag.

Scherer, J., (1965). La Liberté du personnage racinien. [The Liberty of Racinian Characters]. In Le Théâtre tragique, actes des colloques d'Angers (1959) et de Royaumont (1960) (pp. 265269). Paris: Éditions du C.R.N.S.

Schopenhauer, A. (2004). The Art of Literature. (T. B. Saunders, trans.). Mineola \& New York, NY: Dover Publications.

Steiner, G. (1998). After Babel: Aspects of Language and Translation (3rd ed.). Oxford: Oxford University Press.

Sun, Y. (2011). Violence and Translation Discourse. Journal of Multicultural Discourses, 6(2), 159-175.

Venuti, L. (1995). The Translator's Invisibility: A History Translation. London: Routledge.

Venuti, L. (2008). Translation, Interpretation, Canon Formation. In A. Lianeri \& V. Zajko (Eds.), Translation and the Classic: Identity as Change in the History of Culture (pp. 27-51). Oxford: Oxford University Press.

Viala, A. (1992). Qu'est-ce qu'un classique? [What is a classic?]. Bulletin des bibliothèques de France, 37(1), 6-15.

Ward, A. (1970). The Quest for Theseus. London: Pall Mall.

Wilbur, R. (1958). The Misanthrope. London: Faber and Faber. 